\title{
Does our Past have a Motivational Effect? Our Reasons for Acting: Sartre's Philosophy of Action
}

Yoann Malinge (Université Panthéon-Sorbonne, Paris 1)

Sartre is well known for his philosophy of freedom. According to him, man is condemned to be free, which means that his very being makes him free. This being is the pour-soi which Sartre puts in contrast with the being of the en-soi, the being of the world. The being of man is called by Sartre le pour-soi, in so much as consciousness exists for him who is aware of it. The things of the world are simply themselves, without any consciousness. A thing is en-soi, it is what it is and just what it is. By contrast, the pour-soi has no essence. It exists, Sartre would say, as a nothingness. This thesis is related to the definition that Sartre gives to consciousness. Consciousness is not an interiority, a substance in which some states of mind and passions reside. Consciousness is an act. The act of aiming at something, it is always "consciousness of something". That is the thesis of intentionality, that Sartre (Sartre 2003) found in Husserl's philosophy (Husserl 2011, §36; §84).

However, to these abstracts considerations on the being of the pour-soi, Sartre (Sartre 2011, 554) adds that freedom is always in a situation. Man is always in a certain place, in a certain time of his life, in certain relationships with others. Nevertheless, this situation is not determining anything. My connection with it is contingent. I could have been born elsewhere, in another family for example. All the same, I was born in that particular family and to ignore it is to think about an action abstractly whereas it is placed in concrete terms. We can consider that Sartre is going further than Kant by defining the free action not only abstractly, as "the power to inaugurate by oneself a state" (Kant 2006, 495), but as freedom in a given situation. Through his action, man exercises a power from the situation and from outside of the situation. We can say that Sartre completes the Kantian thought of freedom which made it exist in this world and only on a noumenal plane.

Among the elements which make up a situation, there is the person's past. The problem that has to be solved is whether the past plays a part in determining the content of the action. What must be reconciled, if possible, are the thought of the pour-soi as nothingness and the affirmation of freedom in every situation. The thesis that the being of consciousness - the pour-soi - is a 
nothingness means that it cannot have a definition pre-determined for acts. It is not a thing. But, there is another thesis that freedom is always present in any given situation. When I talk of there being freedom in situation, I am talking about being pour-soi.

Is the past something which in freedom in situation is en-soi or pour-soi? This brings us back to the classical problem of determinism and freedom for a philosophy of absolute freedom which does not recognize determinism. That is why I have decided to focus also on the role of the past in the choice of action. Indeed, it is often said that one who acts in a certain way does something which seems like him or on the contrary when one acts in an unexpected way, that he acts in a way "that is not like him". All these observations indicate that the past of the agent is considered as giving shape to future actions. The present action would be inscribed in a continuation of the past. Moreover, we could think that the past has not only a motivational effect, but also creates the reasons for the action. If I act in a certain way, it is not only because my habit, my past impels me, but because I have some reasons to do so, reasons that I perceive precisely because my past has inclined me to this. We have to wonder about the existence of motives and understand how they turn into reasons to act.

\section{The role of the past}

It would be ridiculous to pretend that the past did not exist. Nevertheless, to maintain that the past is the origin of all my actions is simply to assert that which came in front of what I am doing in the present. The origin does not necessarily have any efficient power, it is not a foundation: it is a precedence in the chronology whereas a foundation would be a logical precondition. To know the origin is to know the situation on which and from which I act. I can act bravely after being a coward all my life. The past is a starting point. Is not it then a kind of a springboard? Yes, but a springboard is not a trampoline, it is only the start from which I jump into the void. It is the place from which I go but it does not in itself add any a power to my jump. It has no force of its own. However, it should be viewed as a locus by reference to which one can see that an action is situated. My action is seen to exist in a certain moment of my life.

Thus, the past does not play a determining role for the action nor is it its driving force but it enables the understanding of the action and of the agent. It is the frame in which I act, and from which I act as a pour-soi. I find my bearings in relation to it but it is only a point and it does not indicate the direction in which I am going. I am remote from this point and I can go in all directions. To believe or to make others believe that this starting point determines my actions, it is showing "bad faith" 1 . Sartre does not reject duration as a concept, but he rejects the determining aspect of duration. My action is always marks a clean

\footnotetext{
${ }^{1}$ Originally: «mauvaise foi ».
} 
break from anything that came before though I can always choose to continue it.

The rejection of the determining role of the past takes the same form as the rejection of any determination by a situation.

Sartre asserts that there is a "state of fact" only if a power of nihilation ${ }^{2}$ makes it or, more precisely, reveals it. The separation of consciousness happens in two steps: we stop considering the actual situation as something natural and necessary, and instead we develop an alternative (Sartre 2011, 480). Then, we compare the possible situation and the actual one.

It must be understood that what surrounds the acting subject could constitute a motive for acting only if the subject constitutes it as a motive. To do this, he has to become aware that he is not embedded in the situation, but that he is always separated from it by the nothingness that he is. This separation exists but he is not necessarily conscious of it. We can take the example given by Sartre: the worker of 1830 did not revolt because he lacked "the necessary reflection to conceive a social state in which these suffering would not exist." "He suffered without considering his suffering". His misfortune was "integrated to his being by the worker himself"3. However, he was wrong. With an awareness, called by Sartre $(2011,480)$ "a pure tearing away of himself" because our being may have become embedded - it becomes possible for the worker to set down his suffering as unbearable. In other words, the phenomenological description shows well the duality of the constitution of the motive and so the ineffectiveness of the situation as such. The first step consists in tearing oneself away from the world, from the being. Why is a tearing needed if we understand the pour-soi as the being which is not what it is, as a power of nothingness? The tearing enables one to be aware of this power of nihilation and to fight against the state of fact of myself in a figure, in a role, which prevents me from being what I am, that is a nothingness. The situation itself tends to freeze me in a role. If I allow myself to be taken in, I will be guilty of bad faith. Then, in the second step, it becomes possible to describe the state of fact thus revealed as an unbearable condition. It is then and only then that a motive for action exists, something that drives the actor to act. Thus there is neither the sociological nor the historical determinism insofar as the society is concerned, the social situation is a fact only if the agent is tearing himself away from it and gives it the sense of being unbearable. Without these two steps, the social structures would have no effect.

Do they not have the negative effect, however, of preventing me from acting? The term `stagnation' does not signify a complete lack of power but it

\footnotetext{
${ }^{2}$ Originally: «pouvoir de néantisation » or « puissance néantisante ».

3 Originally: "L'ouvrier de 1830 ne se révolte pas parce qu'il manque de «la réflexion nécessaire pour lui faire concevoir un état social où ces souffrances n'existeraient pas». «Il souffre sans considérer sa souffrance». Ses malheurs «sont intégrés par l'ouvrier à son être»".
} 
ascribes to me a negative power, one that retains. We could then say that social structures do after all have an effect, namely that of inertia on the agent. The example of the worker helps correct this misunderstanding. It is not the social structures themselves that prevent him from acting, it is the subject himself or herself that prevents it, but not in a conscious way. Misfortunes are "not detached, they are not seen in clear light". But who does not tear away from them? Who does not see them in clear light? It is the worker himself, and "consequently, they are incorporated by the worker to his being" (Sartre 2011, 479; emphasis added). He is suffering from a poor understanding of his relation to the en-soi. Here, Sartre denies the efficacy of these socio-economic structures in so much as they are a state of fact only if the pour-soi is tearing itself away by its annihilating power. The responsibility therefore rests on the acting subject.

The second part of this quote shows that it takes the same movement in order for the past to constitute a motive for action. One must "tear himself away [from the past] in order to be able... to give it a meaning". Without these two steps, there is neither a determination of the action by the past, nor an obstacle to act insofar as, ontologically, the pour-soi is always already separated from its past by nothingness. "A rupture", "a tear". However, our past has bogged us down in inertia and we must tear ourselves away. In itself, a situation does not even make sense, it's up to us to give it meaning. Since it has no meaning in itself, it cannot give direction to action. It is only retrospectively that we understand the sense of the past, that we give it a meaning and that we can explain the action by a causal system. On its own the past has no power.

The past has no power because its existence is very special: As the past, it has only an "honorary existence". This qualification shows the existence of the past - which is not denied - but it also shows its lack of power. It serves only by representation, as the Queen of England only represents authority and public power. In fact, the Queen has no power over state affairs. Similarly, the past is there, it is a state that I was in, but it has no power over the current business I lead. Moreover, just like the Queen, the past can be unnoticed, it can be no more than a part of the decoration. It is like the greatness that has disappeared and is irrelevant to the present day because, of both not being relevant to the present time and because of not being in actuality. If the past remains, this is because we maintain it in existence. We invite the past to appear in a project for the future. This is because there is a project to realize that the past is called on, the past is chosen for the recall. It is not given to us; we are here and now and when it's time to act, we must confront the past. In other words, either choose to go in the direction that it was, to continue in the same way because this is our project or choose to follow a different way.

How does the constitution of the en-soi give rise to a motive that adds meaning to the situation? Does the meaning come first and only then does the agent plan to do something from the meaning he has been given? The answer to the latter question is negative. The meaning and the project are simultaneous. 
The relation between the motive and the act should not be seen as a relation of cause and effect. The motive does not exist before the action. There is one simultaneous emergence of the motive, of the action and of the end. In other words, Sartre raises the possibility that a pre-motive would have a power of determining and triggering the action. In fact the motive has a meaning and exists only if there is an action and an end. The act has a meaning if there is a motive and an end. The end has a meaning if there is a motive and an act.

In fact, Sartre argues that we should be more rigorous. First it seems that the act decides the motive and the end. And it depends on nothing other that freedom, which is temporalizing nihilation. I start acting when I take the step back that allows me to have a motive and to target an end. It is this nihilating distance and this donation of the meaning of the situation which constitute the motive and the start of action. Here, Sartre seems to have a broad understanding of the action. It exists when both the motive and the end exist. However, there is no need for the initial gestures, or physical movements. That is because Sartre equates "the resolute project" with the action. Here is a specific example: I decide to act with an environmental protection group. For the moment, I do not move, I am still in my office. This decision, however, is already an act according to Sartre, it is firstly a project to campaign for ecology and secondly a step back from the situation in which I am, namely a member of a consumer society and living without taking into account the environmental impact of my lifestyle. This is assuming that it is possible that I could act to protect the environment, that is to say at the same time considering that I could live differently, outside of a thoughtless consumption model, and that my decision is forged and I am driven to act.

Sartre refuses to consider either the motives or the reasons as transcendent. They do not exist before the project does, they have a value thanks to the project. So it is the project that is the basis of motives and reasons. I do an action not because a motive exists, but because it is a part of my project which gives value to this motive. Thus there is no real deliberation on my part here since motives have the value that I give to them and when I deliberate, the decision has already been made. In fact, I do realize the presence of motives and this awareness through deliberation is precisely in my project (Sartre 2011, 495). It is the project that gives motives their value and therefore dictates that the decision is made. The project concept is crucial. We should question what has led us to adopt such a project, to carry out such a project in so much in as it decides what actions are to come. Thus we wonder - has Sartre not just pushed the process of determination back one stage?

Since there is no real deliberation, the will does not choose between choices. The decision is already made. The will therefore occurs only in triggering action. 


\section{The reasons for the action}

The objective characteristic of the reason is taken from the world, in the aim that the pour-soi has. However, the reason remains an "assessment" of the situation. Such is the special nature of this intentionality of consciousness that it can refer both practically and scientifically to the world. In front of a field of flowers, the biologist will see the future possibility of seed dispersal. Looking at the same field, a young lover will see the opportunity to pick flowers for his loved one. Thus we see that the appreciation of the reason in the world is based on the project of the pour-soi. It is because the romantic's project is to seduce that he sees in the field a reason to pick flowers.

The reason does not determine the action, "it appears only in and through the project of an action" (Sartre 2011, 493). The appearance of the reason and the fact that consciousness cut engraves it into the reality of a situation is therefore the result of a particular way of aiming at reality, the way of a pour-soi engaged in a project. This is quite subjective. It is not the en-soi which is the creator of the reason. The reason has a sense and thus existence as such only because of the being pour-soi.

There are two theses that are rejected. On the one hand, there is the thesis that the en-soi or the world determines the action. It does not and to imply otherwise would be to say that the en-soi lacks its own being and has a need to be changed and in some sense completed or fulfilled. A forest destroyed by fire does not of itself call for replanting in so much as the fire allows its regeneration by the emergence of new trees. The en-soi is full of itself and its changes do not require outside intervention, they are the effect of a natural causality ${ }^{4}$. On the other hand, there is the argument that there could exist a motive that would make the agent perceives reasons for his action. Sartre uses an example of the French king Clovis. Did Clovis conquer Gaul because he was driven by ambition or some other pre-existing motive? Sartre replies in the negative. The king's ambition was "not distinguished from the project to conquer" (Sartre 2011, 493). This project was the motive. It was not because Clovis was ambitious that he wanted to conquer Gaul, but because he wanted to conquer Gaul we can say that he was ambitious. We find here again a theory opposed to psychologism, or at least to any theory which bases the source of actions in the "self", in the ego. What comes first? Not the qualities of the ego, but the project. And this is the very being of the pour-soi according to Sartre. It is this projection that illuminates the world and reveals reasons. This revelation is also donating the sense of reason. Ultimately, it is the being-in-the-world of the agent which is the source of reasons, motives and ends.

There is no act without a reason. Does this mean that the reason is a cause of action within the meaning of natural causality? Again, Sartre replies in the negative. As for the motive, we should not hypostatize the reason. The

\footnotetext{
${ }^{4}$ Neither is it a question of asserting any end.
} 
motive is always a motive for an agent and it should be "experienced as such" says Sartre $(2011,481)$. However, it is not necessary that the reason be posed by consciousness. It exists and it need not be reflected on since the object of consciousness is the action. As for the motive, the reason only has the value given it by the pour-soi adopting the project.

If we base this thesis in Sartre's ontology we are able to understand what Sartre means when he says that "man is condemned to be free" $(2011,164$; 484).

At the very moment when I try to cling to my reasons, I understand that I am always beyond them, always free to change, to remove their value, to escape from them. There is within this concept a form of responsibility which causes anxiety. My reasons may explain my action, but they never determine it completely. I am beyond them and I am the only agent. This is an absolute responsibility which causes anxiety. There is no action without me, therefore motives and reasons cannot be considered as a cause in the sense of the natural cause of a phenomenon. In this way Sartre's philosophy is a philosophy of freedom and is against determinism. Although the situation offers the agent some reasons to act, the pour-soi is always separated from them. In his absolute responsibility, he gives them meaning. Man is therefore condemned to be free.

\section{Literature}

Husserl, E. 2011. Idée directrices pour une phénoménologie (Ideen I).Trans. P. Ricœur. Paris: Gallimard.

Kant, I. 2006. Critique de la raison pure. Trans. A. Renaut. Paris: Flammarion. Sartre, J.-P. 2011. L'être et le néant. Paris: Gallimard.

Sartre, J.-P. 2003. "Une idée fondamentale de la phénoménologie de Husserl : L'intentionnalité. Situations I". In: Sartre, J.-P. La Transcendance de l'Ego et autres textes phénoménologiques. Paris: Vrin. 
Yoann Malinge (Université Panthéon-Sorbonne, Paris 1)

\title{
Does our Past a have Motivational Effect? Our Reasons for Acting: Sartre's Philosophy of Action
}

\begin{abstract}
The goal of my paper is to consider how one chooses one's own action. First, I will try to understand how both his past and his environment can condition someone's action. According to Sartre, we can act without being determined by our past which is always separated from us. It will be important to understand how such a process is possible. Is man completely free to act? Then I will raise the question of our reasons for acting in order to show that reasons do not pre-exist in the world. Motives are always motives for an agent who gives them meaning. They never condition the action completely. By his project, the agent reveals some reasons to act and these reasons have a value only in relation to the project adopted by the agent. Therefore, we can say that everyone is condemned to be free.
\end{abstract}

Keywords: Sartre, action, freedom, past, motives, reasons for acting.

Ethics in Progress (ISSN 2084-9257). Vol. 4 (2013). No. 2. pp. 46-53. 